Images in...

\title{
Epidural pneumatosis as a consequence of cocaine use
}

\author{
Humza Malik, Shailesh Mohandas, Dipankar Mukherjee \\ Department of Upper GI Surgery, Queens Hospital, BHR Hospitals Trust, Romford, Essex, UK \\ Correspondence to Mr Humza Malik, humza.malik@gmail.com
}

\section{DESCRIPTION}

A previously healthy 22-year-old gentlemen was referred to the surgical department following acute onset epigastric pain. The initial onset of pain was followed by an episode of vomiting and wretching lasting an hour. On examination, although the abdomen was tender in the epigastrium there was no evidence of peritonitis. Crepitus was evident in the neck and anterior chest wall due to extensive subcutaneous emphysema. Plain radiographs illustrated linear lucencies tracking in the neck and chest, but no pneumothorax or free intra-abdominal air. CT illustrated marked subcutaneous emphysema throughout the mediastinum and neck (figures 1 and 2). Furthermore free air was identified in the spinal canal. Gastroscopy and contrast swallow did not identify any oesophageal perforation. After further careful history taking, the patient admitted cocaine abuse. The patient was treated conservatively and symptoms resolved after $48 \mathrm{~h}$. The mechanism of cocaine-induced subcutaneous emphysema is believed to be secondary to barotrauma; after deep inhalation and Valsalva maneouvre in order to increase uptake and the euphoriant effect, or cough triggered by the sniffed substance. This resulting increased intra-alveolar pressure causes rupture of a distended alveolus into the lung interstitium. Air then dissects along the pulmonary vasculature toward the hilum and then extravasates into the posterior mediastinum. It may then travel through the neural formamina into the epidural space. Air thus freely communicates via the neural foramina and collects in the epidural space. ${ }^{1-3}$ This case illustrates a previously unreported complication of cocaine use and highlights the difficulty in differentiating between oesophageal perforation which produces similar clinical and radiological appearances.

\section{Learning points}

- Pneumomediastinum as a result of oesophageal perforation carries a significantly poorer prognosis then following drug abuse, with death rates of between $10 \%$ and $60 \%$.

- Thus it is crucial to carefully rule out gastrointestinal perforation as a cause in order to implement appropriate management immediately.

Competing interests None.

Patient consent Obtained.

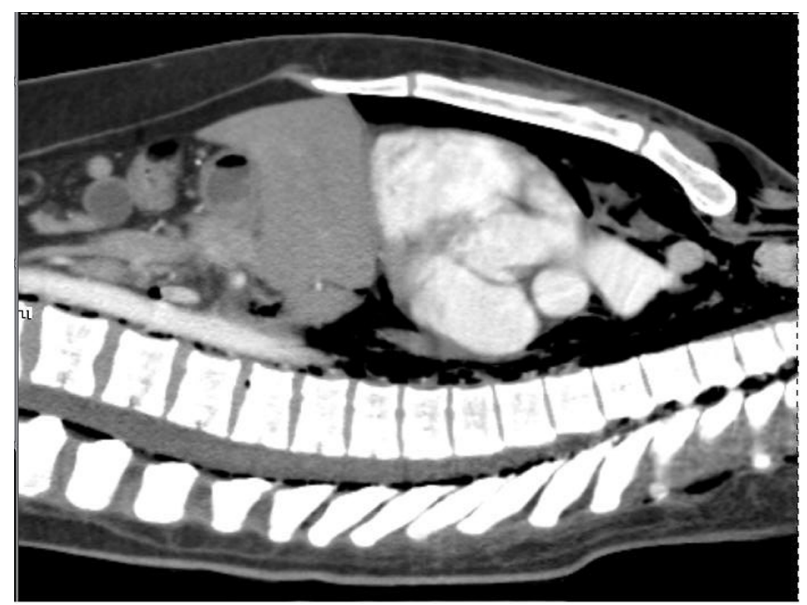

Figure 2 Saggital CT images demonstrating significant pneumomediastinum and epidural pneumatosis .

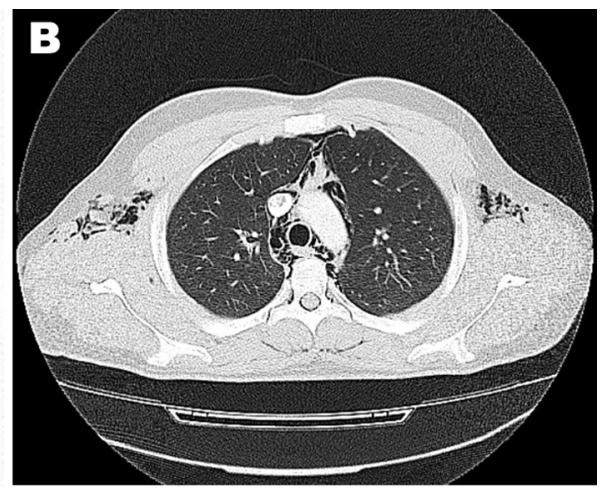

Figure 1 Transverse CT images demonstrating pneumomediastinum and epidural pneumatosis. 


\section{BMJ Case Reports}

\section{REFERENCES}

1. Alnas M, Altayeh A, Zaman M. Clinical course and outcome of cocaineinduced pneumomediastinum. Am J Med Sci 2010;339:65-7.
2. Janes SM, Ind PW, Jackson J. Images in Thorax. Crack inhalation induced pneumomediastinum. Thorax 2004;59:360.

3. Maeder M, Ullmer E. Pneumomediastinum and bilateral pneumothorax as a complication of cocaine smoking. Respiration 2003;70:407.

This pdf has been created automatically from the final edited text and images.

Copyright 2012 BMJ Publishing Group. All rights reserved. For permission to reuse any of this content visit http://group.bmj.com/group/rights-licensing/permissions.

BMJ Case Report Fellows may re-use this article for personal use and teaching without any further permission.

Please cite this article as follows (you will need to access the article online to obtain the date of publication).

Malik H, Mohandas S, Mukherjee D. Epidural pneumatosis as a consequence of cocaine use. BMJ Case Reports 2012;

10.1136/bcr.2012.006171, Published XXX

Become a Fellow of BMJ Case Reports today and you can:

- Submit as many cases as you like

- Enjoy fast sympathetic peer review and rapid publication of accepted articles

- Access all the published articles

Re-use any of the published material for personal use and teaching without further permission

For information on Institutional Fellowships contact consortiasales@bmjgroup.com

Visit casereports.bmj.com for more articles like this and to become a Fellow

Keep up to date with all published cases by signing up for an alert (all we need is your email address) http://casereports.bmj.com/cgi/alerts/etoc 